\title{
Breast Cancer cM0 TNM Finding v8
}

National Cancer Institute

\section{Source}

National Cancer Institute. Breast Cancer cMO TNM Finding v8. NCI Thesaurus. Code C139393.

Breast cancer without clinical or radiog raphic evidence of distant metastases. Imaging studies are not required to assign the cM0 category. (from AJCC 8th Ed.) 